Working Paper

Series
IIIIIIFINRISK

National Centre of Competence in Research Financial Valuation and Risk Management

National Centre of Competence in Research

Financial Valuation and Risk Management

Working Paper No. 743

\title{
Agency Issues and Financing Constraints - Evidence from REITs
}

\section{Manish Gupta}

First version: J anuary 2012

Current version: J anuary 2012

This research has been carried out within the NCCR FINRISK project on

"Behavioural and Evolutionary Finance" 


\title{
Agency Issues and Financing Constraints - Evidence from REITs
}

\author{
Manish Gupta * \\ Institute for Banking and Finance, \\ University of Zurich, \\ Zurich, Switzerland
}

First Draft: May, 2011

Current Draft: January 30, 2012

\begin{abstract}
${ }^{*}$ Keywords: CF, X. Financial support by the National Centre of Competence in Research "Financial Valuation and Risk Management" (NCCR FINRISK) is gratefully acknowledged. This study was conducted under the NCCR FINRISK research project, Behavioural Finance (Thorsten Hens). Comments are welcome. Contact: manish.gupta@bf.uzh.ch. I thank my adviser Thorsten Hens and also Michal Dzielinski, Ruediger Fahlenbrach, Amit Goyal, Michel Habib, Henrik Hasseltoft, Andreas Loepfe, Per Ostberg, Cornelius Schmidt, Urs Schweri, Rene Stulz, Alex Wagner, Alex Ziegler and seminar participants at ERES (2011), Gerzensee Doctoral Wrokshop (2011), and Zurich Economics Workshop (2011) for valuable suggestions and discussions.
\end{abstract}




\begin{abstract}
Given a firm's investment policy, its dividend policy is irrelevant (Miller and Modigliani (1961)). REITs, by law, pay at least $90 \%$ of their corporate income as dividends, so that their dividend policy is given. This is a reversal of the dividend irrelevance theorem through regulatory means. Such a high dividend payment also means lower retained earnings, leaving firms with little free cash flow. Jensen (1986) argues that lower free cash flow results in mitigated agency problems. In this paper, I ask two questions. First, how does an average REIT, given its dividend policy restricted through regulation, respond to its investment opportunities? Second, does an average REIT, with mitigated agency problems, face less severe financing constraints? In response to the first question, I find that an average REIT's investment responsiveness (as measured by Tobin's $q$ ) is higher than that of firms in other industries. In response to the second question, I find that, despite mitigated agency costs, an average REIT faces, in fact, more severe financing constraints (as measured by sensitivity to cashflow) than other firms. Finally, using the natural experiment provided by the 2001 REIT Modernization Act (RMA) that allowed REITs to own taxable REIT subsidiaries (TRS) and reduce their dividend distribution from $95 \%$ to $90 \%$, I show that, for a given increase in internal funds, the negative impact arising from increased agency problems dominates the positive impact of the wealth effect, resulting in a lower overall responsiveness of REITs to their investment opportunities.
\end{abstract}




\section{Introduction}

In 1960, Congress created Real Estate Investment Trusts (REITs) in the US. Coincidentally, a year later, Miller and Modigliani (1961) rigorously proves dividend irrelevance theorem which says given a firm's investment policy, its dividend policy is irrelevant. REITs are stipulated by law to remit at least 90 percent of their corporate income into dividends so their dividend policy is given. This flips the dividend irrelevance theorem. The first question, I ask how an average REIT, given its dividend policy, responds to its investment opportunities. Such a high dividend payment also means lower retained earnings so little free cash flow. Jensen (1986) argues lower free cash flow mitigates agency problems. My second question is if an average REIT (with mitigated agency problems) faces lower financing constraints. For the first question, I find that, for manufacturing firms, on average, one standard deviation increase in $q$ results in 0.13 standard deviation increase in investment responsiveness whereas for REITs one standard deviation increase in $q$ results in 0.17 standard deviation increase in investment responsiveness. For the second question, I find that an average REIT faces, in fact, higher financing constraints than other firms. For manufacturing firms, on average, one standard deviation increase in cashflow results in 0.04 standard deviation investment - cashflow sensitivity whereas for REITs one standard deviation increase in cashflow results in 0.06 standard deviation investment - cashflow sensitivity. Therefore, despite having lower free cash flow agency issues, REITs face more severe financing constraints compared to manufacturing firms. These statistically significant differences are economically meaningful.

Effective from 2001, REIT Modernization Act (RMA) allowed REITs to own taxable REIT subsidiaries (TRS) and reduce the dividend distribution requirement from $95 \%$ to $90 \%$. In other words, RMA allowed REITs, first, to add and diversify their product mix widening their investment opportunity set and, second, to retain more earnings for investment purposes. Given this policy change which I exploit as a natural experiment in our study for exogenous variation (in dividends payout and $q$ ), I find that higher free cash flow lowers the investment responsiveness by escalating financing constraints despite a simultaneous increase in internal funds and $q$.

A REIT is a firm that owns, and in most cases, operates income-producing real estate. In 1960, Congress created REITs in the U.S. as a means to facilitate an easy access for small investors to invest in large-scale, income-

producing real estate. Prior to REITs, access to the investment returns of commercial real estate equity as a core asset was more or less confined only 
to institutions and wealthy individuals. In order for a firm to qualify as a REIT in the US, it must comply with certain ground rules specified in the Internal Revenue Code including an investment of at least $75 \%$ of total assets in real estate, deriving at least $75 \%$ of gross income as rents from real property or interest from mortgages on real property and distributing annually at least $90 \%$ of taxable income to shareholders in the form of dividends. A firm that qualifies as a REIT is permitted to deduct dividends paid to its shareholders from its corporate taxable income.

Higher dividend payouts can make it much harder for management to squander the funds on wasteful projects. Jensen (1986) argues the optimal mechanism to achieve the goal is to increase the leverage since it is more difficult for management to renege on a debt than on dividends. However, for REITs, at least 90 percent of the corporate income has to be paid in dividends to retain the status so a renege on dividends payment is out of question. Free cash flow is also viewed as a channel where wealth is transferred to debtholders from shareholders. Just as shareholders want to increase dividends to the maximum extent to discipline managers, debtholders may want to limit dividends to avoid the problems of debt overhang (Myers (1977)) and risk shifting (Jensen and Meckling (1976)). Since for REITs dividend policy is already put in place before any debt is issued, debtholders, aware of the fact that the most of the earnings would be transferred to shareholders, can design the terms of contract optimally (Myers (1977)).

It is an important policy question how government can influence investment in an industry by altering its dividend policy. If one of the objectives back in 1960 when the US Congress enacted REITs law was to increase investment in real estate, it seems it has served some of its purpose over time. According to NAREIT, listed U.S. REITs in 2010, constitute a more than $\$ 300$ billion equity market with an average daily trading volume of about $\$ 4$ billion. Unlisted REITs in the U.S. now manage assets of more than $\$ 70$ billion and are adding another $\$ 7$ billion annually.

\section{Literature Review}

There are mainly two lines of thoughts serving as foundational grounds for majority of studies in dividend literature - Lintner (1956) and Miller and Modigliani (1961). On the basis of results from a survey with corporate professionals Lintner (1956) documents that managers decide dividends policy first and other policies are adjusted taking dividend policy as given. Almost after 50 years since Lintner (1956) study, Brav, Graham, Harvey and 
Michaely (2004) documents that firms still determine their dividend and investment policy together. On the other hand, Miller and Modigliani (1961) rigorously shows that, given a firm's investment policy in a perfect and complete capital markets, dividends have no relevance on its value.

Unarguably, Miller and Modigliani (1961) is based on very simplistic assumptions, a number of studies followed afterwards with interesting implications by relaxing those assumptions. Most notably of them are signaling or asymmetric information based studies such as Bhattacharya (1979), John and Williams (1985) and Miller and Rock (1985). In our setting, signaling explanations have only limited relevance because of two reasons. First, dividend policy is already regulated so dividends cease to be a discretionary variable in the hands of management. Second, there is no taxation on dividends for REITs and tax is the cost of signal (for it to be credible) in most studies.

Grullon, Michaely, and Swaminathan (2002) proposes an explanation that develops the relation between dividend changes and risk changes also known as "maturity hypothesis". It says a firm pays dividends when it becomes mature in its life cycle resulting in one with a shrunk investment opportunity and a concomitant decline in risk. For REITs, this explanation may not hold since they are required to pay a high rate of dividends right from their inception. Another study by Baker and Wurgler (2004) or catering theory of dividends is based on argument that managers pay dividends to satisfy investors' changing preferences for dividends. For REITs, dividends have to be paid each period regardless of investors' preferences so this study has limited explanation for the present context.

Explaining dividends as a means to restrict agency problems comes long way. Easterbrook (1984) notes three sources of agency concerns. One source of agency concern is between management and shareholders as advocated by Jensen and Meckling (1976) and Jensen (1986) where managers maximize their gains at firm's cost. Second source of agency costs originates between debtholders and the management acting in interests of shareholders. While Myers (1977) shows how debt overhang may preclude management to take positive NPV projects, Jensen and Meckling (1976) documents how risk shifting behavior may induce managers to undertake riskier projects at the cost of debtholders. The third source of agency costs is risk aversion on the part of managers as documented by Marcus (1982). The intuition is that managers have substantial part of their personal wealth tied to their firms. If firms perform poorly or go bankrupt, managers will lose their jobs and, even worse, it may be harder for them to find similar opportunities somewhere else. Thus, managers' personal risk aversion can make them 
choose projects that are safer than necessary. Agency based explanations for dividend payouts are more suitable to our context even though dividend payment for REITs is a regulatory restriction.

Literature on financing constraints widely known as investment cash flow sensitivity is enormous. Hubbard (1998) and Schiantarelli (1996) document excellent reviews. The equation estimating financing constraints used by several studies including Fazzari, Hubbard, and Petersen (1988, 2000, hereafter FHP) is following:

$$
\text { Investment }_{i t}=\alpha_{i}+\alpha_{t}+\beta q_{i, t-1}+\gamma \text { Cashflow }_{i t}+u_{i t}
$$

The interpretation for this equation is that in a frictionless world, with a measure of marginal $q$, investment's response to its opportunities should be one to one. Therefore, the coefficient on $q$ should be unity and coefficient on cash flow (which is used as a measure of firm's net worth) should be zero. However, in the presence of frictions and with a less than perfect estimate of average $q$, the coefficient on $q$ could be less than unity and the coefficient on cash flow is positive. FHP establishes, in nutshell, higher the magnitude of the coefficient on cash flow, the higher the degree of financing constraints a firm faces.

$q$ is essentially a marginal concept in the sense that it establishes the connection between investment and increase in firm value via incremental capital stock but marginal $q$ remains unobserved. Hayashi (1982) lays out the conditions for equality of marginal and average $q$. It says that for a price taker firm (in a perfectly competitive output market) if both of its production function and cost of adjustment function are linearly homogenous of same degree, average and marginal $q$ are equal. If these conditions are not met, average $q$ turns out to be a potentially poor proxy for marginal $q$. Other potentially serious issues with the usage of average $q$ include endogeniety (Poterba (1988)) and measurement error (Erickson and Whited (2000)).

Kaplan and Zingales $(1997,2000)$ raise skepticism on the validity of cash flow sensitivity to investment. One of the potential issues is the usage of an a priori variable to classify firms with varying degree of financial constraints. They argue that the choice of an a priori variable is endogenous and also choice of such variable could be correlated with investment cash flow sensitivity. So, it might serve a poor or sensitive proxy. As a result, the cross sectional analysis may become sensitive to the choice of such a priori variable. Moreover, single variable might not reveal any non linearity of sensitivity of investment cash flow sensitivity if it exists among different 
firms. In this study, I do not employ any a priori variable to classify firms on the scale of financial constraints. Second potential concern they raise is on the validity of assumption of monotonicity of financial constraints with respect to cash flow. This issue is still largely unresolved in the literature. Kaplan and Zingales (1997) were able to exploit qualitative information of the firms in their sample due to its small size to create an index which is later termed as KZ index by Lamont, Polk, and Saa-Requejo (2001). Using a larger sample and broader time horizon, Whited and Wu (2006) construct Whited $\mathrm{Wu}(\mathrm{WWu})$ index to measure the degree of financial constraints a firm may face. As Whited and $\mathrm{Wu}$ (2006) point out the usage of such indices is subject to temporal and cross sectional variation.

Studies such as Hu and Schiantarelli (1998) and Hovakimian (2009) attempt to circumvent the issue of a priori classification adopting alternative approaches. Hu and Schiantarelli (1998) adopts an endogenous regime switching regression model to classify firms into different states but the problem is only partly resolved with this technique since the number of regimes may be limited. Hovakimian (2009) uses the error term from the estimation of above equation to classify firms into different investment cash flow sensitivity groups. The idea is the average of the error term should not be very significantly different between high and low cash flow states for an unconstrained firm. The potential limitation with this approach is that it rules out the possibility for a firm to have both unconstrained and constrained periods of financing constraints.

Lamont (1997) and Blanchard, Lopez-de-Silanes, and Shleifer (1994) analyze the sensitivity of investment to cash flow shock for smaller and focused samples. Lamont (1997) analyzes the role of internal capital markets for a small sample of firms in oil industry with non-oil subsidiaries. He documents how a shock in cash flow for oil business in those companies affects the investment in non-oil business with no change in investment opportunities. Blanchard, Lopez-de-Silanes, and Shleifer (1994) asks how managers disburse windfall funds with no change in investment opportunities. They find that managers do not return the funds to the stakeholders of the firm. Their results emphasize the role of agency issues.

This is not the only study that examines the financing constraints for REITs. Gentry and Mayer (2005) has already examined the investment responsiveness of REITs. The focus of this study differs from that study. This study compares the investment responsiveness of REITs with that of firms in other industries instead of examining firms within REITs industry. 


\section{Hypotheses Development}

The intuition can be imparted parsimoniously with figure 1 . The capital stock is on the horizontal axis whereas risk-adjusted cost of capital is on the vertical axis. $D$ is downward sloping curve for a firm's demand for capital. In a perfect world of Modigliani and Miller (1958) with no frictions, the supply schedule is $r r^{\prime}$. Internal funds and external funds are perfect substitutes for each other. In figure 1, $r c$ is the amount of internal funds and $c r^{\prime}$ is the amount of external funds. The equilibrium is achieved at point $a$ with the capital stock, $F$ and risk adjusted cost, $r$.

However, the world is far from being so perfect and there do exist frictions such as asymmetric information and agency problems. In the presence of frictions, internal and external funds cease to be perfect substitutes for each other. Therefore, the supply curve becomes $r c S 0$. The slope of the curve, $\mathrm{cS} 0$, is determined by the degree of frictions the firm faces. The segment, $r c$, still represents firm's internal funds at its disposal. The risk adjusted cost of internal funds is $r$ which is also the risk-adjusted firm's cost of capital. $O W 0$ may be considered as firm's net worth. For external funds, firm pays a higher price than its shadow cost of internal funds, $r$. The premium is due to frictions. The equilibrium is attained where demand schedule $D$ and supply curve, $r c S 0$, intersect each other. Now, the equilibrium price is $b$ which is higher than the firm's cost of capital, $r$ and new quantity of capital is $K$ which is lower than that of the first best, $F$.

Let's consider an impact of lower internal funds on the equilibrium holding else constant. At net worth, $O W 1$, the internal funds are shrunk to $r e$ from $r c$. Since it is assumed, nothing else changes so the demand curve and the slope of $e S 1$ portion of supply curve remains unchanged. With this new supply curve, we have a new equilibrium. The price is $d$ which is even higher than $b$ and new quantity is $L$ which is even lower than $K$. With lower internal funds, firm pays even higher price to get $a b$ lower amount of external funds in presence of frictions. Figure 1 is the same figure as appeared in Hubbard (1998). It simply says that in presence of frictions, external funds are costlier than internal funds. As FHP acknowledges it is an asymmetric information setting. This result is in the spirit of Myers and Majluf (1984) where in presence of asymmetric information between firm and outside investors, internal funds are preferred.

The frictional premium could be due to asymmetric information quite as much as due to agency problems. In Blanchard, Lopez-de-Silanes, and Shleifer (1994), agency effect of an increase in cash flow is nothing but the effect of free cash flow for a given set of investment opportunities. However, 
the equation given in the previous section can not simply distinguish between cash flow and free cash flow. Free cash flow hypothesis implies that firm with a free cash flow spends it on wasteful projects. If so, outside investors will add the layers of frictional premium in tandem with level of free cash flow a firm has. Therefore, higher the free cash flow a firm has, larger the frictional premium it pays.

Next we consider the impact of lower free cash flow in figure 2. Let us assume that the firm has not only lower net worth, re, but also lower free cash flow. Jensen (1986) argues that lower free cash flow lowers agency costs. Consequently, the slope of the supply curve for external funds becomes less steep and rotates downwards to $r e S 2$ from $r e S 1$. With this new supply curve we have a new equilibrium at $f$ where the firm now pays a lower price $f$ than $d$ and gets even higher amount of capital, $M$ than $L$. So with the same amount of internal funds, a firm with a lower free cash flow is likely to be less financing constrained than the similar firm with higher free cash flow. In our context, REIT's supply schedule should be reS2 resulting in lower financing constraints. Based on the discussion, two hypotheses are formed:

Hypothesis 1: Given its dividend policy, how does an average REIT respond to its investment opportunities?

Hypothesis 2: Ceteris paribus, whether an average REIT with lower free cash flow (implying mitigated agency costs) faces lower financing constraints for its investment needs when it accesses capital markets to obtain external funds.

To capture the cross sectional differences in cash flow (or net worth) among firms, several studies have employed various a priori variables to classify firms on varying degree of financing constraints. For instance, FHP uses dividend payouts and Whited (1992) uses leverage ratios as a priori variable to classify firms. Firms that make higher dividend payouts are likely to be less financing constrained than firms that make lower payouts. Similarly, firms with lower leverage are expected to be less financing constrained than firms with higher leverage. Interestingly, as we will see later, for REITs both - dividend payouts and leverage ratios - are high. In this paper, I do not use any a priori variable to classify firms. 


\section{Empirical Results}

\subsection{Data and Summary Statistics}

I obtain the data from COMPUSTAT for firm specific accounting information, I/B/E/S for analysts' coverage, and CRSP for firms' beta from 1985 to 2010. The sample starts from 1985. Following literature, manufacturing firms are taken as the control group. The identification strategy is as follows: I classify firms with SIC code 6798 as REITs since this code is exclusively allotted to only REITs. Firms with SIC code between 1999 and 4000 are classified as manufacturing firms.

The variables are defined as follows. Firm investment is measured as capital expenditures (item128) scaled by total assets (item6). Cashflow is measured as the sum of the income before extraordinary items (item18) and depreciation and amortization (item14) scaled by total assets (item6). Tobin's $q$ (average) is calculated as market value of equity (item 24 multiplied by item 25) plus book value of assets minus book value of equity minus deferred taxes (item 6 - item 60 - item 74), scaled by total assets (item6). Our proxy for free cash flow variable is the total cash dividends paid by a firm in a year (item 19) scaled by total assets (item 6). The idea is higher the dividend payout, lower the free cashflow a firm has. Due to high correlation with cashflow, retained income which would have been an ideal free cash flow variable is not employed in our analysis. Firm size is measured as natural logarithm of total assets (item6). Leverage is measured as long-term debt (item9) plus short-term debt (item34) divided by total assets (item6). Cash is defined as cash holding (item1) scaled by total assets (item6). Net Income is measured as net income (loss) (item 172) scaled by total assets (item6). Analyst coverage is the headcount of analysts following a firm in a given year. Firms' betas are obtained from CRSP files. It is calculated on annual-basis using daily returns from the market model.

Our final sample comprises 63693 firm-year observations for 6745 firms and 26 years (1985-2010). Out of which, manufacturing firms account for 62149 firm-year observations for 6494 firms and REITs account for 1544 firm-year observations for 251 firms. (Due to non-availability of information on cashflow, the sample size for REITs has greatly reduced from 4160 firmyear observations for 425 firms to 1544 firm-year observations for 251 firms.)

Table 1 summarizes means, standard deviations and medians of the key variables in our sample. The first 3 columns belong to REITs and the next 3 columns belong to manufacturing firms. The last column is the median test for non-parametric Kruskal-Wallis statistic. Median cashflow for man- 
ufacturing firms is significantly higher at 0.07 than that of REITs at 0.03. Median value of total assets for REITs at $\$ 487.41$ millions is substantially higher than that of manufacturing firms at $\$ 103.47$ millions. A $q$ greater than unity calls for investment; it can be seen that the median Tobin's average $q$ is the higher for manufacturing firm at 1.5 than REITs at 1.12. Following the same pattern as that of $q$, mean investment for manufacturing firms is substantially higher at 0.05 than that of REITs at 0.01 . One observation that stands out is the leverage ratio of REITs compared to manufacturing firms. The median leverage ratio of REITs is 0.49 which is more than 2.5 times that of the manufacturing firms at 0.18. Jensen's (1986) argument for lower agency problems arising out of free cash flow was made for issuance of debt. For REITs, we can see that they not only pay higher dividends but have higher leverage also. This statistic fosters our intuition of REITs may face lower agency issues from a lower free cash flow. As can be expected, median cash or internal liquidity is lower for REITs at 0.02 than that of manufacturing firms at 0.10 . As expected, mean value of dividend to asset ratio is higher for REITs at 0.06 than that for manufacturing firms at 0.01 . Median net income is similar for both groups at 0.03 . All sample statistics for the two groups are statistically different from each other as $p$ values from respective non-parametric Kruskal Wallis test statistics reject the null of equality.

\subsection{Main results}

$$
\text { Investment }_{i t}=\alpha_{i}+\alpha_{t}+\beta_{1} \text { Cashflow }_{i t}+\beta_{2} q_{i, t-1}+\beta_{3} \text { DivPay }_{i t}+u_{i t}
$$

The variables investment, cashflow, and $q$ are as defined as previously for equation 1 . The new variable in equation 2 is dividend payout (scaled by assets) that is our proxy for potential free cash flow issues. Retained earning would have been a better choice but due to multicollinearity, we employ dividend payout. Our intuition is higher the dividend payout, lower is the likelihood of a firm with high free cash flow. For firm and time effects, we have firm and year dummies.

I estimate the equation 2 using firm fixed effects model. To overcome potential outliers issue, I winsorize all the variables at 1 percent on both tails. Recently, there has been a number of very insightful papers ${ }^{1}$ enriching our understanding regarding the efficiency gains from alternative ways

\footnotetext{
${ }^{1}$ See Angrist and Pischke (2008), Petersen (2009), Stock and Watson (2008) and also Thompson (2011).
} 
of clustering (one way or two way) of standard errors from panel data estimation. Thompson (2011) points the gains from two way clustering are limited if there exists a fixed effect in the data and two way clustering may do more harm than good if the panel is too unbalanced. Our panel is very unbalanced and also there is a significant fixed effect present in every regression. I, therefore, cluster the error in the model by firm in constructing efficient standard errors.

Table 2 reports the estimation results of the above equation for REITs and manufacturing firms with and without our free cash flow variable. First 3 columns report results for REITs and the following next 3 columns for manufacturing firms. The results pertain to three different variants of the above equation. The results of first variant which was employed by FHP are reported in column 1 for REITs and column 4 for manufacturing firms. Dependent variable is investment and explanatory variables are cashflow and $q$ along with year and firm dummies.

In FHP, higher the magnitude of coefficient on cashflow, greater a firm is said to be dependent on its net worth or internal funds, hence more likely to be financing constrained. In column 4 , the coefficient on cashflow is 0.012 and the coefficient on $q$ is 0.004 for manufacturing firms. Both coefficients are statistically significant at $99 \%$ significance level. For REITs (column 1), the coefficient on $q$ is 0.006 which is statistically significant at most conventional levels but the coefficient on cashflow is 0.01 which is not statistically significant so cannot be distinguished from zero. It implies, in the spirit of FHP analysis, that REITs do not face financing constraints. In FHP, an a priori variable which is used to distinguish firms between financing constrained and financing unconstrained is dividend payout. The logic is dividend payout level is likely to be inversely related to the degree of financing constraints a firm faces. If this is true, then REITs' are less likely to be financing constrained because of very high dividend payout. In this paper, no a priori variable is used to classify firms on the scale of financing constraints.

In column 3 and 6 , the estimation results are reported including dividend payout variable in our specification for REITs and manufacturing firms. For REITs, the coefficient on cashflow, 0.018, has turned statistically significant, coefficient on $q$ has remained same at statistically significant 0.006 as before and the coefficient on dividend payout, 0.318, is negative and statistically significant. It seems it was causing some omitted variable bias. The negative coefficient implies that such a high dividend payout, in fact, depresses investment for REITs. On the other hand, for manufacturing firms, we find that the coefficient on cashflow has declined slightly than before at 
0.011, coefficient on $q$ is still at .004 and the coefficient on dividend payout is 0.167 implying that higher dividend payout helps investment. All coefficients for manufacturing firms are statistically significant at conventional levels. Different signs on dividend payout for the two groups seem to imply that agency issues are relatively more important than asymmetric information for manufacturing firms but for REITs, the order of importance seems to be reversed. The adjusted R-squared is 0.47 and 0.68 for manufacturing firms and REITs, respectively. The F-test statistic shows there is considerable fixed effect. To test the equality of coefficients from the two regressions, I conduct an incremental $\mathrm{F}$ test with a $p$ value of 0.001 suggesting that the coefficients from the two samples are not equal. A pooled regression would have been another alternative but the key assumption for pooled regression is the variance in two groups be equal. I test the equality of variances (of the residuals drawn from pooled regression) between the two groups and found that null of equality of variances is rejected with $p$ value even less than 0.0001 .

In summary, from the analysis above, two main results emerge. First, an average REIT's responsiveness to its investment opportunities is a bit higher than that of an average manufacturing firms and second, an average REIT faces greater financing constraints than an average manufacturing firm.

Over time, burgeoning literature on investment cash flow sensitivity has established the variation of additional controls on investment. In this section, I try to control for additional variables such as size, cash, leverage, debt rating and analyst coverage. Our specification equation, is, now:

$$
\begin{aligned}
\text { Investment }_{i t}= & \alpha_{i}+\alpha_{t}+\beta_{1} \text { Cashflow }_{i t}+\beta_{2} q_{i, t-1}+\beta_{3} \text { DivPay }_{i t}+\gamma_{1} \text { Size }_{i t} \\
& +\gamma_{2} \text { Cash }_{i t}+\gamma_{3} \text { Leverage }_{i t}+\gamma_{4} \text { AnalystCoverage }_{i t}+u_{i t}
\end{aligned}
$$

For equation 3, the variables - investment, cashflow, $q$ and dividend payout are as defined as before. We saw in the univariate statistics (table 1) that a median REIT has a larger size than a median manufacturing firm. Size may affect our results since firms with smaller size may be subject to higher likelihood of adverse selection problems affecting their investment given cash flow and investment opportunities. As documented by Huberman (1984), many investment opportunities are of 'now or never' nature and if not undertaken at the right time, they may vanish away. In such cases, cash holding as precautionary motive serves as a vital source of liquidity for funding. There are two additional benefits from holding cash. First, 
firms do not have to incur transaction costs to frequently raise funds. In a structural approach, Gamba and Triantis (2008) documents the importance of cash holding for financial flexibility by incorporating the costs of debt issuance. Second, information asymmetry between managers and capital market participants makes liquidity valuable as shown by Myers and Majluf (1984). Cash could also serve a general purpose buffer against future cash shortfalls. Lins, Servaes, and Tufano (2009) terms cash as unconditional liquidity, funds at firm's disposal. Acharya, Almeida, and Campello (2006) develops a model which presents cash as a dynamic hedging tool. Debt is issued to hoard cash so that a constrained firm can channel it across low cash flow states. Another study by Almeida, Campello, and Weisbach (2004) develops a model that documents the cash flow sensitivity of cash which may affect the investment. Due to all such reasons, cash holding is included as a control variable in the equation. Table 1 reports that median REIT seems to have a higher leverage than median manufacturing firm. A firm with higher leverage may be facing a higher probability of debt overhang issues (Myers (1977)). Alternatively, risk shifting argument, where firm's management in the interests of shareholders, takes up only risky projects at the expense of debt holders is equally valid (Jensen and Meckling (1976)). Clearly, both issues affect investment. More analysts coverage for a firm implies more information production for that firm resulting in less information asymmetry. This variable may be useful to assess the degree of asymmetric information especially for those firms that do not have debt rating.

Table 3 reports the results from the above extended model. As earlier, first three columns report results for REITs and the following three columns report results for manufacturing firms. The cash flow sensitivity of investment is much higher for REITs at 0.023 than that for manufacturing firms at 0.008. Similarly, the investment responsiveness of REITs is also slightly higher for REITs at 0.006 compared to 0.005 for manufacturing firms. While dividend payout affects positively the investment for manufacturing firms (0.152), it affects negatively the investment for REITs (-0.314). All these coefficients are statistically significant. Other controls such as cash and leverage are not significant for REITs but they have negative and statistically significant impact on investment for manufacturing firms. The coefficient on number of analysts is positive and statistically significant for both groups but the magnitude is almost zero. Interestingly, size has a negative impact on REITs investment but the magnitude is a way too small to imply any meaningful impact. The goodness of fit is tighter for REITs with adjusted R-squared coefficient of 0.68 than that for manufacturing firms at 0.48. Apparently, there is still some heterogeneity that remains unexplained 
for manufacturing firms. The $p$ value of the $\mathrm{F}$ test for equality of coefficients at 0.001 rejects the null of equality of coefficients. To summarize, an average REIT's responsiveness to its investment opportunities is higher and faces severer financing constraints compared to an average manufacturing firm.

Real estate is traditionally known to be a hedge against other financial assets due to its low correlation with them. Several studies such as Geltner, Miller, Clayton and Eichholtz, (2007) document that the risk characteristics of real estate as an asset class falls between bonds and stocks. It is a possibility that our current specification might not be capturing the riskrelated differences in the cost of funds for the different groups as pointed by Hubbard (1998). Besides, given a high level of leverage for REITs (table 1), one may argue that debt overhang issue could prevent some REITs to invest that may produce a downward bias. No investment, no financing constraints. Though the argument holds for new projects, high leverage itself reflects the riskiness of a firm. As a next exercise, I control for risk related differences between REITs and manufacturing firms by including beta into the equation. Beta estimates are collected from CRSP files. CRSP estimates betas using market model for daily returns on yearly basis. To capture the inter-industry cross-sectional variation, I now pool the two groups together to estimate the following equation.

$$
\begin{aligned}
\text { Investment }_{i t}= & \alpha_{i}+\alpha_{t}+\delta D+\beta_{1} \text { Cashflow }_{i t}+\beta_{2} q_{i, t-1}+\beta_{3} \text { DivPay }_{i t} \\
& +\beta_{4} \text { Size }_{i t}+\beta_{5} \text { Cash }_{i t}+\beta_{6} \text { Leverage }_{i t}+\xi_{1} D * q_{i t} \\
& +\xi_{1} D * \text { Cashflow }_{i t}+\xi_{3} D * \text { DivPay }_{i t}+\xi_{4} D * \text { Cash }_{i t} \\
& +\xi_{5} D * \text { Size }_{i t}+\xi_{6} D * \text { Leverage }_{i t}+\gamma_{1} \text { Beta }_{i t} \\
& +\gamma_{2} \text { AnalystCoverage }_{i t}+u_{i t}
\end{aligned}
$$

In the above equation, a binary variable $\mathrm{D}$ is created such that it takes value 1 for REITs and 0 otherwise. Other variables are as defined as before for the equations $1-3$. The results from the above equation 4 for pooled regression for both groups are reported in table 5 to be discussed in details in the next section.

The coefficients of prime interest are the $\xi \mathrm{s}$ in equation 4 . These coefficients measure the differential sensitivities for REITs. For REITs, we can note that the coefficients on interaction of REIT dummy, $D$ with $q$, $\xi_{1}$, and the interaction with cashflow, $\xi_{2}$, are both positive and statistically 
significant. Higher dividend payout negatively affects REITs' investment. A negative coefficient on leverage for manufacturing firms may suggest the relevance of debt overhang issues but no such impact seems to affect REITs.

\subsection{Natural Experiment}

The Congress created REITs in 1960 to encourage small investors to invest in real estate firms. Over time, the horizon of REITs has changed considerably. Probably responding to the changed horizon, on December 17, 1999, Congress and the President signed into law the REIT Modernization Act (RMA) to go into effect from January 1, 2001. Two main features of RMA are to allow REITs to own taxable REIT subsidiaries (TRS) and reduce the dividend distribution requirement from $95 \%$ to $90 \%$. This legislation allows REITs, first, to widen their investment opportunity set and, second, to retain more earnings. While an increase in internal funds may facilitate more and cheaper funds for investment, such an increase also raises the likelihood of its abuse by managers by having now an access to a higher amount of free cash flow.

To illustrate these dynamics intuitively and more lucidly, we refer to figure 3. Let us consider, first, the impact of an increase in investment opportunities. In figure 3 , it shifts the demand schedule $D$ rightwards to $D^{\prime}$. This shift results in more capital stock needed from $M$ to $P$ suggesting an increase in investment, all else being equal. Next, let us consider the impact of increase in internal funds. Increase in internal funds, ceteris paribus, has two effects - wealth effect and agency effect. First, such an increment in internal funds eases the financing constraints by having more funds available at so it should lead to increase in investment. Second, such an increment also increases the amount of free cashflow for a firm therefore raising the possibility of its abuse leading to an increase in frictional premium demanded by the market causing a downward impact on investment. Which of the two effects dominates may differ across firms. In figure 3, this increases the level of internal funds by $e e^{\prime}$. However, this increment in internal funds may also intensify the frictions faced by firms due to increases in free cash flow. This development is depicted by a leftward rotation of the upward sloping portion of the supply curve from $e S 2$ to $e^{\prime} S 2^{\prime}$. Now, the supply schedule, $r e^{\prime} S 2^{\prime}$, is steeper than before. Finally, the new equilibrium is attained at the intersection of the new demand schedule, $D^{\prime}$, and supply schedule, $r e^{\prime} S 2^{\prime}$ with $O Q$ units of capital at the $\operatorname{cost} c$. In the figure, the new equilibrium depicts an increase in capital for investment from $O M$ to $O Q$ but it is certainly not a deterministic outome. 
This legislation (RMA) constitutes a natural experiment in our setting. One popular way to evaluate the impact of RMA legislation in a panel data setting is to estimate differences-in-differences estimator. Literature on differences-in-differences (hereafter, DID) estimator is enormous ${ }^{2}$. So far, our analysis is based on the variation provided by cross sectional characteristics of the explanatory variables in our specification. One of the potential concerns is the validity of our analysis in the presence of endogeneity. Poterba (1988) points out that it is hard to see what is driving what due to endogeneity concerns. The natural experiment approach or policy change provides a very useful source of identification strategy. By providing exogenous variation, policy changes help us to get rid of endogeneity concerns. The source of variation in investment for REITs, after RMA, is coming through dividends and $q$ as explained in figure 3. Table 4 reports summary statistics of REITs and manufacturing firms before and after the change. As expected, we can see for REITs in panel A that median $q$ increased from 1.09 during pre RMA to 1.17 in post RMA period. Correspondingly, median dividend payout decreased from 0.04 to 0.03 after RMA. Leverage and assets size increased while net income fell after RMA. In panel B, for manufacturing firms also, median $q$ increased from 1.47 to 1.59 during the same period but dividend payout remains more or less unchanged after 2000. In contrast with REITs, leverage fell from 0.19 to 0.14 after 2000 for manufacturing firms. The differences in statistics between the two periods for both groups are statistically significant.

For DID estimation, we need two groups - one that is affected by the policy change and the other not. We also need two time periods - one accounting for pre-policy and the other accounting for post-policy change. If we have such a setting, we can generate two binary variables - one for treatment group and the other for treatment period and the interaction of these two binary variables will capture the precise impact of the policy change on the outcome of the affected group in post-policy change period. The regression equation for measuring the impact after RMA is as follows:

\footnotetext{
${ }^{2}$ See Card(1990), Bertrand, Duflo, and Mullainathan (2004), Card and Krueger(1994) and also Meyer (1995).
} 


$$
\begin{aligned}
\text { Investment }_{i t}= & \alpha_{i}+\alpha_{t}+\zeta \text { trend }+\phi(\delta * D)+\rho_{1} D+\rho_{2} \delta+\eta_{1}(\delta * D) * q \\
& +\eta_{2}(\delta * D) * \text { Cashflow }_{i t}+\eta_{3}(\delta * D) * \text { DivPay }+\beta_{1} q_{i, t-1} \\
& +\beta_{2} \text { Cashflow }_{i t}+\beta_{3} \text { DivPay }_{i t}+\beta_{4} \text { Size }_{i t}+\beta_{5} \text { Cash }_{i t} \\
& +\beta_{6} \text { Leverage }_{i t}+\xi_{1} D * \text { Cashflow }_{i t}+\xi_{2} D * \text { DivPay }_{i t} \\
& +\xi_{3} D * q_{i t}+\xi_{4} D * \text { Cash }_{i t}+\xi_{5} D * \text { Size }_{i t}+\xi_{6} D * \text { Lvrge }_{i t} \\
& +\gamma_{1} \text { Beta }_{i t}+\gamma_{2} \text { AnalystCoverage }_{i t}+u_{i t}
\end{aligned}
$$

In equation 5, we create two binary variables - one for REITs, $D$ (as in equation 4), and another for RMA, $\delta$. The coefficient on the interaction of these two binary variables, $\widehat{\phi}$, is our DID estimator. In essence, the variable that captures DID is nothing but a dummy variable that takes value 1 for REITs in post-RMA period. This dummy variable, however, captures only the impact of policy change, RMA, on investment for REITs. It is an important policy question but for our study the impact of financing constraints and investment responsiveness of REITs on investment after the change are even more important. To capture the net change in the investment responsiveness and financing constraints for REITs after the policy change, I simply interact the DID variable with cashflow and $q$ to capture net differences in sensitivities. I also interact DID variable with dividend payout.

One may plausibly argue that manufacturing firms may not be an appropriate control group for REITs for DID estimation. I argue this is not so. Undeniably, there still may be some heterogeneity between REITs and manufacturing firms which may remain unobserved in our specification but the key identifying assumption of fixed effect estimation is that such unobserved heterogeneity is captured by fixed effects. It is also true that fixed effect captures only time invariant unobserved heterogeneity but in our specification we also have time dummies to capture any time variant effect. It is fair to argue that year dummies are fixed in nature in the sense they do not allow variation of any specific year effect over time so we include a trend variable to capture time varying heterogeneity across the firms in these two groups. The only assumption which allows us to run DID estimation is that the investment in two groups would have remained similar if there had not been a policy change. Other variables carry the same interpretation as for equations $1-4$. As previously, all variables are winsorized at both tails by one percent. Following Bertrand, Duflo, and Mullainathan (2004) and 
Rauh (2006), standard errors are clustered by industry to address the issues of serial correlation since in our study the unit of policy change is industry.

Equation 5 fully nests equation 4 so I report results for only equation 5 . Estimation results from equation 5 are reported in table 5 . The DID estimator, $\phi$, is 0.012 implying that the an average REIT's investment increased compared to that of a manufacturing firm's due to RMA amendment. The associated $p$ value asserts its statistical significance. The coefficient on interaction of DID and cashflow variable is positive, 0.008 , and statistically significant implying that the financing constraints for REITs increased after RMA. Note that, in figure 3, we showed that increase in internal funds will have both effects - wealth effect and agency effect, simultaneously. For a given increase in internal funds, wealth effect would imply easing of the financing constraints whereas an agency effect would imply intensification of the financing constraints. The striking finding what this coefficient seems to suggest is that the positive impact of increase in internal funds is completely dominated by the negative impact of increase in free cash flow. The coefficient on interaction of DID and $q$ is negative, -0.004 , and also statistically significant implying that the investment responsiveness of REITs after RMA declined despite an increase in investment opportunity set (table 4). A lower payout has a significant positive effect, 0.144, on the investment for REITs after RMA. In nutshell, it may be concluded that while an increase in retained income helps, higher agency issues associated with the higher level of internal funds has exacerbated the financing constraints so much for REITs that it results in lower responsiveness to their investment opportunities.

Coefficient on risk, beta, is marginal. Coefficient on trend, $\zeta$, is negative but too small to signify any presence of a time varying changes in time effects. Coefficients on treatment dummy is negative, -0.007 , implying that the investment fell for both groups after 2000. So, given a positive, DID estimator, $\widehat{\phi}(0.012)$, it implies that investment for REITs after RMA inched up only relatively to manufacturing firms.

\section{Concluding remarks}

An important question why some firms face more financing constraints than others keeps haunting the finance literature on a regular basis. Most studies compare varying degree of financing constraints for a set of firms within a group of supposedly similar industries (manufacturing firms). This paper evaluates the impact of a single friction on financing constraints in an interindustry comparison. The key result is that agency problems can substan- 
tially escalate the financing frictions resulting in higher financing constraints even when there is a positive wealth effect. 


\section{References:}

Acharya, V., Almeida, H., and Campello, M., 2007, "Is cash negative debt? A hedging perspective on corporate financial policies" Journal of Financial Intermediation 16, 515-554.

Akerlof, G., 1970, "The market for 'lemons': quality and the market mechanism", Quarterly Journal of Economics 84, 488-500.

Almeida, H., Campello, M., and Weisbach, M.S., 2004, "The cash flow sensitivity of cash", Journal of Finance, 59, 1777-1804.

Angrist, J \& J. Pischke, 2008, "Mostly Harmless Econometrics: An Empiricist's Companion", Princeton University Press.

Baker, M. and Wurgler, J., 2004, "A Catering Theory of Dividends", Journal of Finance 59, 1125-1165.

Bertrand, M. Duflo, and E. Mullainathan, S., 2004, "How Much Should We Trust Differences-In-Differences Estimates?", Quarterly Journal of Economics, 119, 249-276.

Bhattacharya, S., 1979, "Imperfect information, dividend policy, and 'the bird in the hand' fallacy", Bell Journal of Economics, 10, 259-270.

Blanchard, O., Lopez-de-Silanes, F., and Shleifer, A., 1994, "What do firms do with cash windfalls?", Journal of Financial Economics 36, 337-360.

Brav, Alon, John R. Graham, Campbell R. Harvey and Roni Michaely, 2005, "Payout Policy In The 21st Century", Journal of Financial Economics, 77, 483-527.

Cameron, C. and Pravin K. Trivedi, 2005, "Microeconometrics: Methods and Applications", Cambridge University Press.

Card, David, 1990, "The Impact of Mariel Boatlift on the Miami Labor market", Industrial and Labor Relations Review, 39(4), 527-538.

Card, D and A. Krueger, 1994, "Minimum Wages and Employment: A Case Study of the Fast-Food Industry in New Jersey and Pennsylvania." American Economic Review, 84(4), 772-93.

Fazzari, S.M., R.G. Hubbard, and B.C. Petersen, 1988, "Financing Constraints and corporate investment", Brookings Papers on Economic 
Activity, 141-195.

Fazzari, S. M. Hubbard, R. G. and Petersen, B. C., 2000,

"Investment-Cash Flow Sensitivities Are Useful: A Comment on Kaplan and Zingales", Quarterly Journal of Economics, 115, 695 - 706.

Easterbrook, EH, 1984, "Two agency-cost explanations of dividends", American Economic Review, 74, 650-659.

Eichholtz, Piet, 2008, "How Does the Market for Corporate Control Function for Property Companies?", The Journal of Real Estate Finance and Economics, 36, 141-163.

Fama, E E, and K R French, 1993, "Common risk factors in the returns on stocks and bonds", Journal of Financial Economics 33, 3-56.

Gamba, A. and Triantis, A., 2008, "The Value of Financial Flexibility. The Journal of Finance", 63, 2263-2296.

Hovakimian, G., 2009, "Determinants of Investment Cash Flow Sensitivity.", Financial Management, 38, 161-183.

Geltner, Miller, Clayton and Eichholtz, 2007, "Commercial Real Estate Analysis and Investments", SWEP.

Grullon, G , R Michaely and B Swaminathan, 2002, "Are dividend changes a sign of firm maturity?", The Journal of Business 75, 387-424.

Hubbard, R.G., 1998, "Capital market imperfections and investment", Journal of Economic Literature 36, 193-227.

Hayashi, F., 1982, "Tobin's Marginal q and Average q: A Neoclassical Interpretation ", Econometrica, 50, 213-224.

Huberman, G., 1984, "External finance and liquidity", Journal of Finance 39, 895-908.

Jensen, M C, 1986, "Agency costs of free cash flow, corporate finance, and takeovers", American Economic Review 76, 2, 323-329.

Jensen, M., Meckling, W., 1976, "Theory of the firm: managerial behavior, agency costs, and ownership structure", Journal of Financial Economics 305-360.

John, K , and J Williams, 1985, "Dividends, dilution, and taxes: a 
signaling equilibrium", Journal of Finance, 40, 1053-1070.

Kaplan, S.N., and L. Zingales, 1997, "Do investment-cash flow sensitivities provide useful measures of financing constraints?", Quarterly Journal of Economics ,112, 159-216.

Kaplan, S.N., and L. Zingales, 2000, "Investment-cash flow sensitivities are not valid measures of financing constraints", Quarterly Journal of Economics, 115, 707-712.

Lamont, O., 1997, "Cash flow and investment: evidence from internal capital markets", Journal of Finance, 52, 83?109.

Karl V. Lins, Henri S., P. Tufano, 2010, "What drives corporate liquidity? An international survey of cash holdings and lines of credit", Journal of Financial Economics, 98, 160-176.

Lintner, J, 1956, "Distribution of incomes of corporations among dividends, retained earnings, and taxes", American Economic Review, 46, 97-113.

Marcus, Alan J., 1982, "Risk Sharing and the Theory of the Firm," Bell Journal of Economics, 369-78.

Gentry, W. and C. Mayer, 2003, "What Can We Learn About the Sensitivity of Investment to Stock Prices with a Better Measure of Tobin's q?" Working paper, Williams College.

Meyer, B., 1995, "Natural and Quasi-Experiments in Economics", Journal of Business \& Economic Statistics, 13(2), 151-161.

Miller, M , and E Modigliani, 1961, "Dividend policy, growth and the valuation of shares", Journal of Business , 34, 411-433.

Miller, M , and K Rock, 1985, "Dividend policy under asymmetric information", Journal of Finance, 40, 1031-1051.

Modigliani, F., Miller, M., 1958." The cost of capital, corporation finance, and the theory of investment", American Economic Review, 48, 261-297.

Myers, S C, 1977, "Determinants of corporate borrowing", Journal of Financial Economics, 5, 147-175.

Myers, S. C , and N S Majluf, 1984, "Corporate financing and investment decisions when firms have information that investors do not have", Journal 
of Financial Economics, 13, 187-221.

Petersen, Mitchell A., 2009, "Estimating Standard Errors in Finance Panel Data Sets: Comparing Approaches", Review of Financial Studies, 435-480.

Poterba, J., 1988, "Comment on 'Financing Constraints and corporate investment", Brookings Papers on Economic Activity.

Rauh, J. D., 2006, "Investment and Financing Constraints: Evidence from the Funding of Corporate Pension Plans", The Journal of Finance, 61, 33-71.

Rauh, J., 2006, "Own Company Stock in Defined Contribution Pension Plans: A Takeover Defense", Journal of Financial Economics, 81(2), $379-410$.

Schiantarelli, F., 1996, "Financial Constraints and Investment:

Methodological Issues and International Evidence", Oxford Review of Economic Policy, 12, 70-89.

Stein, J., 2003, "Agency Information and Corporate Investment," in G. Constantinides, M. Harris, R. Stulz (eds.), Handbook of the Economics of Finance, Elsevier/North-Holland, Amsterdam.

Stock M. and J. Watson, 2008, "Heteroskedasticity-Robust Standard Errors for Fixed Effect Panel Data Regression", Econometrica, 76(1), $155-174$.

Thompson, S., 2011, "Simple Formulas for Standard Errors that Cluster by both Firm and Time", Journal of Financial Economics, 99(1), 1-10.

Tirole, J., 2005, "The Theory of Corporate Finance", Princeton University Press.

Whited, T, 1992, "Debt, liquidity constraints, and corporate investment: evidence from panel data", Journal of Finance, 47, 1425-1460. 
Table 1: Summary Statistics - 1985-2010

This table reports the summary statistics of key variables for REITs and manufacturing firms. Investment is measured as capital expenditures (item128) scaled by total assets (item6). Cashflow is measured as the sum of the income before extraordinary items (item18) and depreciation and amortization (item14) scaled by total assets (item6). Tobin's q (average) is calculated as market value of equity (item 24 multiplied by item 25) plus book value of assets minus book value of equity minus deferred taxes (item 6 - item 60 - item 74), scaled by total assets (item6). Dividends to assets are dividends paid scaled by total assets (item 6).Firm size are measured as natural logarithm of book assets (item6). Leverage is measured as long-term debt (item9) plus short-term debt (item34) divided by total assets (item6). Cash is defined as cash holding (item1) scaled by total assets (item6). Net Income is measured as net income/loss (item 172) scaled by total assets (item6). Statistical significances for the differences correspond to non-parametric Kruskal-Wallis rank-sum test for medians.

\begin{tabular}{|c|c|c|c|c|c|c|c|}
\hline \multirow{2}{*}{ Variables } & Mean & Std Er & Median & Mean & Std Er & Median & \multirow{2}{*}{$\begin{array}{l}\text { KW } \\
\text { Test }\end{array}$} \\
\hline & \multicolumn{3}{|c|}{ REITS } & \multicolumn{3}{|c|}{ Manufacturing Firms } & \\
\hline Cashflow & 0.03 & 0.18 & 0.03 & -0.05 & 0.58 & 0.07 & 0.0001 \\
\hline Assets & 1626.77 & 3617.65 & 487.41 & 2161.85 & 11982.89 & 103.47 & 0.0001 \\
\hline$q$ & 1.18 & 0.57 & 1.12 & 2.34 & 1.02 & 1.50 & 0.0001 \\
\hline Investment & 0.01 & 0.03 & 0.00 & 0.05 & 0.06 & 0.04 & 0.0001 \\
\hline Leverage & 0.47 & 0.26 & 0.49 & 0.22 & 0.37 & 0.18 & 0.0001 \\
\hline Cash & 0.05 & 0.10 & 0.02 & 0.21 & 0.24 & 0.10 & 0.0001 \\
\hline Div to Assets & 0.06 & 0.28 & 0.04 & 0.01 & 0.05 & 0 & 0.0001 \\
\hline Net Income & 0.03 & 0.14 & 0.03 & -0.10 & 0.62 & 0.03 & 0.0001 \\
\hline
\end{tabular}


Table 2: Investment Cashflow Sensitivity

This table presents the fixed effect investment - cashflow sensitivity results for REITs and manufacturing firms. The dependent variable is investment. And the explanatory variables are cashflow, Tobin'q and dividends including year dummies. The REITs sample has 1484 observations and the manufacturing sample has 60374 observations for 1985-2010. F test for fixed effects is a joint test for intercepts for the firms in fixed effect regression sample. $\mathrm{F}$ test for the equality of coefficients is test of equality of coefficients from the two samples. FHP refers to regression specification of Fazzari, Hubbard, and Petersen (1986) or equation 1. All variables are winsorized at $1 \%$ on both tails. The standard errors are given in parenthesis. The standard errors are estimated after clustering at firm level. ${ }^{* * *},{ }^{* *}$, and $*$ indicate statistical significance at the $1 \%, 5 \%$, and $10 \%$ levels, respectively.

\begin{tabular}{|c|c|c|c|c|c|c|}
\hline & \multicolumn{3}{|c|}{ REITs } & \multicolumn{3}{|c|}{ Manufacturing Firms } \\
\hline & FHP & Model 2 & Model 3 & FHP & Model 2 & Model 3 \\
\hline Cashflow & $\begin{array}{c}0.010 \\
(0.009)\end{array}$ & & $\begin{array}{c}0.018 * * \\
(0.006)\end{array}$ & $\begin{array}{c}0.012 * * * \\
(0.001)\end{array}$ & & $\begin{array}{c}0.011^{* * *} \\
(0.002)\end{array}$ \\
\hline Tobin's 'q' & $\begin{array}{c}0.006^{* * *} \\
(0.002)\end{array}$ & $\begin{array}{c}0.001 \\
(0.002)\end{array}$ & $\begin{array}{c}0.006^{* * *} \\
(0.002)\end{array}$ & $\begin{array}{c}0.004 * * * \\
(0.000227)\end{array}$ & $\begin{array}{c}0.18 * * * \\
(0.027)\end{array}$ & $\begin{array}{l}.004^{* * *} \\
(0.0002)\end{array}$ \\
\hline Div/Assets & & $\begin{array}{c}- \\
0.346^{* * * *} \\
(0.087)\end{array}$ & $\begin{array}{c}- \\
0.318^{* * * *} \\
(0.111)\end{array}$ & & $\begin{array}{l}0.004^{* * *} \\
(0.0002)\end{array}$ & $\begin{array}{c}0.167 * * * \\
(0.027)\end{array}$ \\
\hline Year Dummies & \multicolumn{3}{|c|}{ Yes } & \multicolumn{3}{|c|}{ Yes } \\
\hline Adj. R-squared & 0.66 & 0.47 & 0.68 & 0.47 & 0.47 & 0.47 \\
\hline Observations & 1514 & 3891 & 1484 & 61027 & 60487 & 60374 \\
\hline F Test (Fixed Effect) & 0.000 & 0.000 & 0.000 & 0.000 & 0.000 & 0.000 \\
\hline $\begin{array}{l}\text { F Test (Equality of } \\
\text { coefficients) }\end{array}$ & \multicolumn{6}{|c|}{0.000} \\
\hline
\end{tabular}


Table 3: Investment Cashflow Sensitivity with additional controls

This table presents the fixed effect investment - cashflow sensitivity results for REITs and manufacturing firms. The dependent variable is investment. And the explanatory variables are cashflow, Tobin'q and dividends including year dummies. Other controls are size, cash, leverage and number of analysts. The data and variables are described in the paper. The REITs sample has 1465 observations and the manufacturing sample has 60243 observations for 1985-2010. F test for fixed effects is a joint test for intercepts for the firms in fixed effect regression sample. $\mathrm{F}$ test for the equality of coefficients is test of equality of coefficients from the two samples. All variables are winsorized at $1 \%$ on both tails. The standard errors are given in parenthesis. The standard errors are estimated after clustering at firm level. ***, **, and * indicate statistical significance at the $1 \%, 5 \%$, and $10 \%$ levels, respectively.

\begin{tabular}{lcc}
\hline & REITs & Manufacturing Firms \\
\hline Cashflow & $0.023^{* *}$ & $0.008^{* * *}$ \\
Tobin's 'q' & $(0.01)$ & $(0.002)$ \\
& $0.006^{* *}$ & $0.005^{* * *}$ \\
Div/Assets & $(0.002)$ & $(0.0001)$ \\
& $-0.314^{* * *}$ & $0.152^{* * *}$ \\
Size & $(0.105)$ & $(0.026)$ \\
& $-0.002^{*}$ & Positive \\
Cash & $(0.001)$ & $($ Positive) \\
& -0.003 & -0.033 \\
Leverage & $(0.005)$ & \\
& 0.009 & $-0.015^{* * *}$ \\
Number of Analysts & $(0.006)$ & $(0.001)$ \\
& Positive* & Positive \\
Constant & $(0.00)$ & \\
Year Dummies & 0.017 & $0.023^{* * *}$ \\
\hline Observations & $(0.010)$ & $(0.002)$ \\
Adj R-squared & Yes & Yes \\
F Test (Fixed Effect) - $p$ value & 1465 & 60243 \\
F Test (Equality of coefficients) - $p$ value & 0.68 & 0.48 \\
\hline \hline
\end{tabular}


Table 4: Summary Statistics pre and post-RMA change

This table reports the summary statistics of key variables pre and post-RMA for REITs (Panel A) and manufacturing firms (Panel B). Investment is measured as capital expenditures (item128) scaled by total assets (item6). Cashflow is measured as the sum of the income before extraordinary items (item18) and depreciation and amortization (item14) scaled by total assets (item6). Tobin's q (average) is calculated as market value of equity (item 24 multiplied by item 25) plus book value of assets minus book value of equity minus deferred taxes (item 6 - item 60 - item 74), scaled by total assets (item6). Dividends to assets are dividends paid scaled by total assets (item 6). Firm size are measured as natural logarithm of book assets (item6). Leverage is measured as long-term debt (item9) plus short-term debt (item34) divided by total assets (item6). Cash is defined as cash holding (item1) scaled by total assets (item6). Net Income is measured as net income/loss (item 172) scaled by total assets (item6). Statistical significances for the differences correspond to non-parametric Kruskal-Wallis rank-sum test for medians.

Panel A: REITs

\begin{tabular}{l|ccc|ccc|c}
\hline \multirow{2}{*}{ Variables } & Mean & Std Er & Median & Mean & Std Er & Median & \multirow{2}{*}{$\begin{array}{c}\text { KW } \\
\text { Test }\end{array}$} \\
\cline { 2 - 7 } & \multicolumn{3}{c|}{$1985-2000$} & \multicolumn{3}{c|}{$2001-2010$} & \\
\hline Cashflow & 0.03 & 0.20 & 0.04 & 0.01 & 0.11 & 0.02 & 0.00 \\
Assets & 714.42 & 1439.60 & 233.56 & 3153.42 & 5273.14 & 1510.98 & 0.00 \\
Investment & 0.01 & 0.04 & 0.00 & 0.00 & 0.02 & 0.00 & 0.00 \\
Net Income & 0.03 & 0.15 & 0.03 & 0.02 & 0.13 & 0.02 & 0.00 \\
Leverage & 0.42 & 0.26 & 0.44 & 0.56 & 0.23 & 0.56 & 0.00 \\
$q$ & 1.14 & 0.67 & 1.09 & 1.24 & 0.34 & 1.17 & 0.00 \\
Cash & 0.06 & 0.11 & 0.02 & 0.04 & 0.09 & 0.02 & 0.04 \\
Div to Assets & 0.07 & 0.34 & 0.04 & 0.04 & 0.12 & 0.03 & 0.00 \\
\hline \hline
\end{tabular}

Panel B: Manufacturing Firms

\begin{tabular}{l|ccc|ccc|c}
\hline \multirow{2}{*}{ Variables } & Mean & Std Er & Median & Mean & Std Er & Median & \multirow{2}{*}{$\begin{array}{c}\text { KW } \\
\text { Test }\end{array}$} \\
\cline { 2 - 7 } & \multicolumn{3}{c|}{$1985-2000$} & \multicolumn{3}{c}{$2001-2010$} & \\
\hline Cashflow & -0.03 & 0.52 & 0.07 & -0.09 & 0.68 & 0.06 & 0.00 \\
Assets & 1406.76 & 7982.56 & 73.58 & 3777.63 & 17626.07 & 230.85 & 0.00 \\
Investment & 0.06 & 0.06 & 0.05 & 0.04 & 0.05 & 0.03 & 0.00 \\
Net Income & -0.08 & 0.55 & 0.03 & -0.14 & 0.75 & 0.02 & 0.00 \\
Leverage & 0.23 & 0.25 & 0.19 & 0.21 & 0.56 & 0.14 & 0.00 \\
$q$ & 2.35 & 4.34 & 1.47 & 2.32 & 3.20 & 1.59 & 0.00 \\
Cash & 0.18 & 0.23 & 0.08 & 0.26 & 0.26 & 0.17 & 0.00 \\
Div to Assets & 0.01 & 0.05 & 0.00 & 0.01 & 0.06 & 0.00 & 0.00 \\
\hline \hline
\end{tabular}


Table 5: Investment Cashflow Sensitivity - Pooled regression

This table presents the fixed effect investment - cashflow sensitivity results for REITs and manufacturing firms. The dependent variable is investment. And the explanatory variables are cashflow, Tobin'q and dividends including year dummies. Other controls are size, cash, leverage, beta, trend and number of analysts. The data and variables are described in the paper. The sample has 59250 observations for 19852010. D is dummy variable that takes value 1 if the firm is REIT otherwise 0 . D*Cashflow is the interaction of cashflow and D. D*Tobin's q is the interaction of Tobin's q and D. D*Dividends is the interaction of Dividends and D. D*Size is the interaction of Size and D. D*Leverage is the interaction of Leverage and D. $\mathrm{D}^{*}$ Cash is the interaction of Cash and $\mathrm{D}$. Policydum is a dummy variable takes value 1 if post RMA period otherwise 0. Differences-in-differences (DiD) is the interaction of policydum and D. Cashflow*DD is the interaction of cashflow, policydum and D. Tobin's q*DD is the interaction of Tobin's q, policydum and D. Dividends*DD is the interaction of dividend, policydum and D. F test for fixed effects is a joint test for intercepts for the firms in fixed effect regression sample. $\mathrm{F}$ test for the equality of coefficients is test of equality of coefficients from the two samples. All variables are winsorized at $1 \%$ on both tails. The standard errors are given in parenthesis. The standard errors are estimated after clustering at firm level. ***, **, and * indicate statistical significance at the $1 \%, 5 \%$, and $10 \%$ levels, respectively.

\begin{tabular}{|c|c|c|c|c|}
\hline & Coefficient & Robust Std. Err. & $\mathrm{t}$ - value & $\mathrm{P}>\mathrm{t}$ \\
\hline D*Policydum & $0.012 * * *$ & 0.001 & 12.33 & 0.000 \\
\hline DD*Cashflow & $0.008 * * *$ & 0.002 & 4.66 & 0.000 \\
\hline DD*Tobin's q & $-0.004 * * *$ & 0.000 & -7.93 & 0.000 \\
\hline DD*Dividends & $0.144^{* * *}$ & 0.005 & 27.18 & 0.000 \\
\hline Cashflow & $0.008 * * *$ & 0.002 & 3.77 & 0.000 \\
\hline Tobin' q & $0.004 * * *$ & 0.000 & 13.95 & 0.000 \\
\hline Dividends & $0.178 * * *$ & 0.035 & 5.07 & 0.000 \\
\hline Cash & $-0.032 * * *$ & 0.002 & -21.32 & 0.000 \\
\hline Size & 0.000 & 0.000 & 0.45 & 0.651 \\
\hline Leverage & $-0.015 * * *$ & 0.002 & -6.6 & 0.000 \\
\hline D*Cashflow & $0.004^{*}$ & 0.002 & 1.73 & 0.085 \\
\hline D*Tobin's q & $0.002 * * *$ & 0.000 & 5.43 & 0.000 \\
\hline D*Dividends & $-0.509 * * *$ & 0.036 & -14.07 & 0.000 \\
\hline D*Cash & $0.030 * * *$ & 0.002 & 19.9 & 0.000 \\
\hline D*Size & $-0.002 * * *$ & 0.000 & -5.42 & 0.000 \\
\hline D*Leverage & $0.024 * * *$ & 0.002 & 11.02 & 0.000 \\
\hline Analyst Coverage & Positive & 0.000 & 3.97 & 0.000 \\
\hline Beta & $0.002 * * *$ & 0.000 & 7.18 & 0.000 \\
\hline Policydum & $-0.007 * * *$ & 0.002 & -4.16 & 0.000 \\
\hline Trend & $-0.001 * * *$ & 0.000 & -15.74 & 0.000 \\
\hline Constant & $0.061 * * *$ & 0.002 & 33.77 & 0.000 \\
\hline Year Effects & & Yes & & \\
\hline Adj. R-squared & & 0.50 & & \\
\hline Number of obs & & 59250 & & \\
\hline F(6525, 52682) - Fixed Effect & & 6.785 & & \\
\hline$p$ Value & & 0.000 & & \\
\hline
\end{tabular}




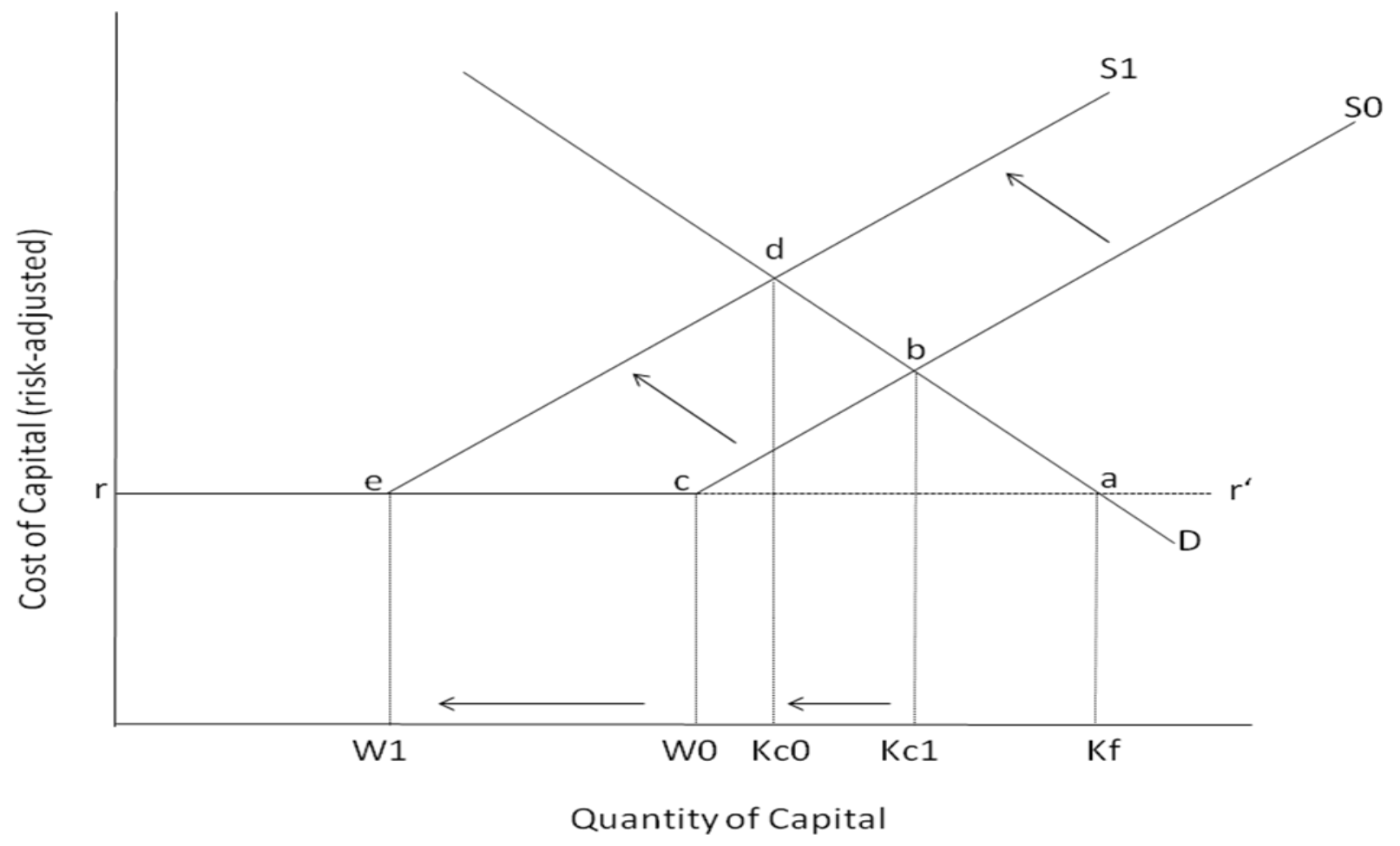

Figure 1

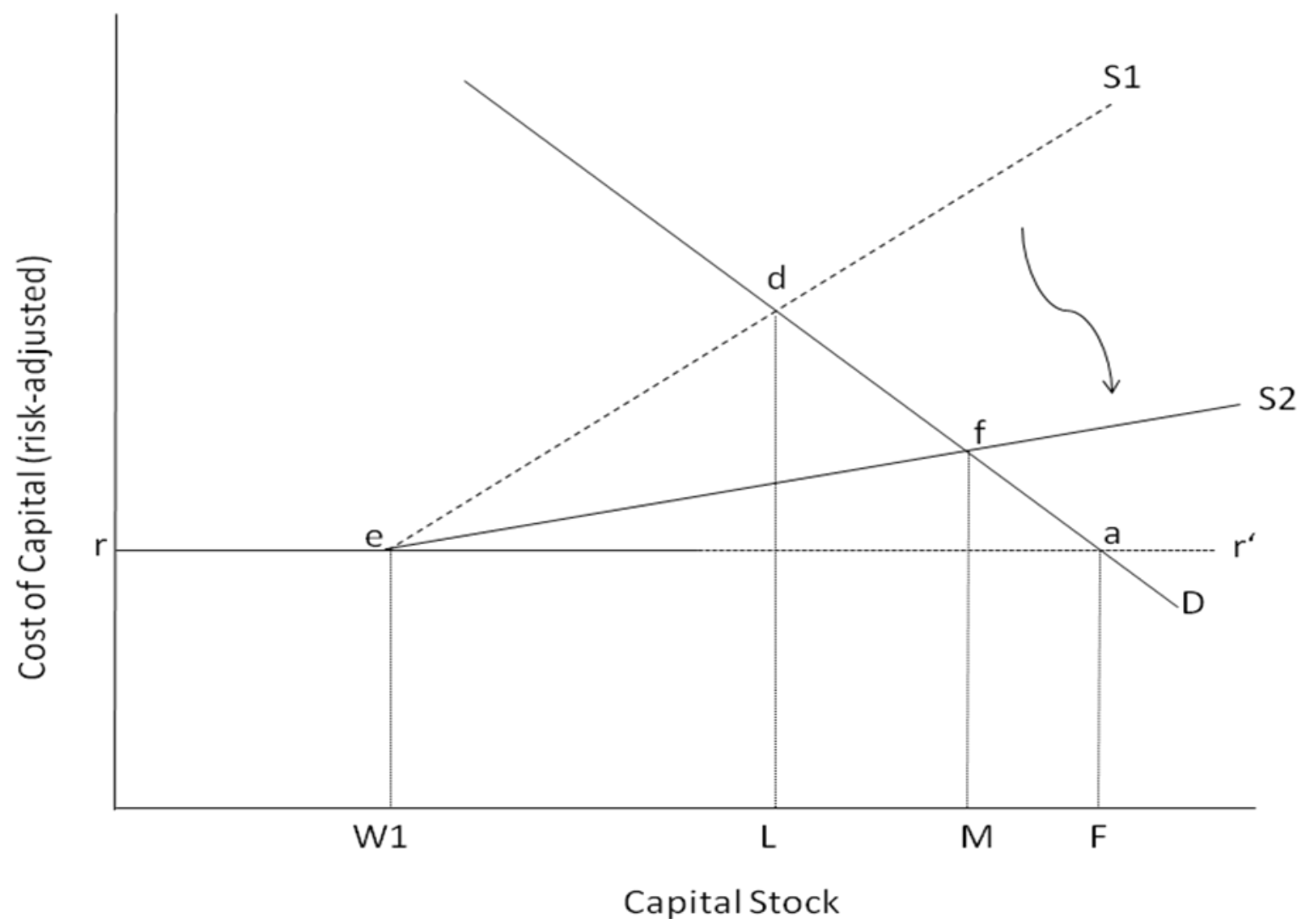

Figure 2 


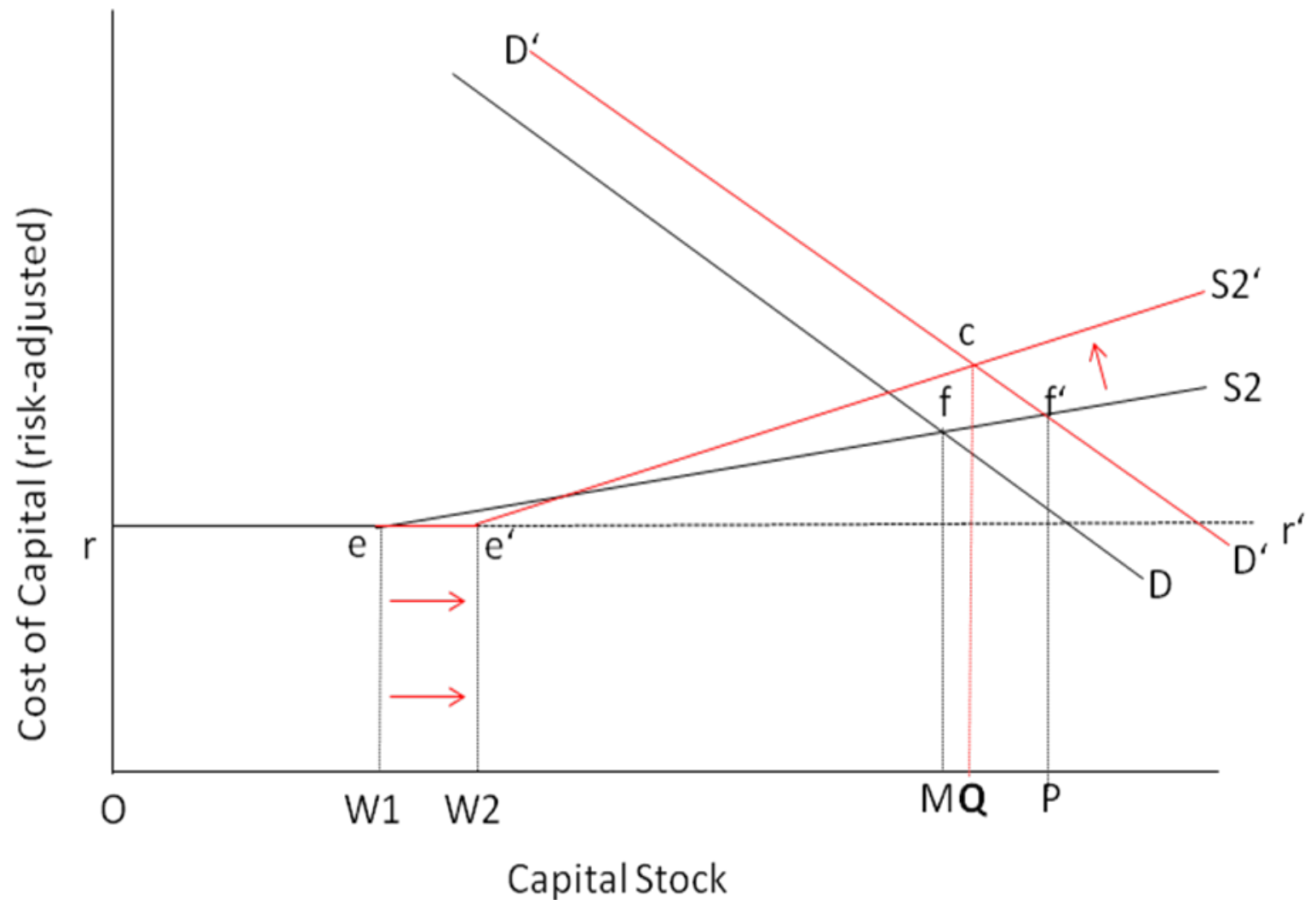

Figure 3 